$$
\begin{aligned}
& \text { تأثير سطوح مختلف تنش خشكى بر مؤلفهاى جوانهزنى دو جمعيت اصفهانى و } \\
& \text { هندى كياه شنبليله } \\
& \text { زهره زمانى '، حمزه اميرى ب* و احمد اسماعيلى }
\end{aligned}
$$

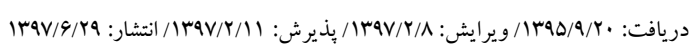

$$
\begin{aligned}
& \text { 'خروه زيستشناسى، دانشكدة علوم بايه، دانشكاه لرستان، خرم آباد، ايران }
\end{aligned}
$$

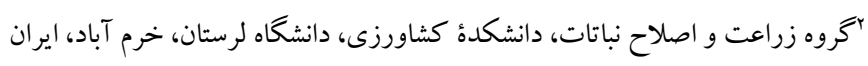

$$
\begin{aligned}
& \text { amiri.h@lu.ac.ir :مسئول مكاتبات }
\end{aligned}
$$

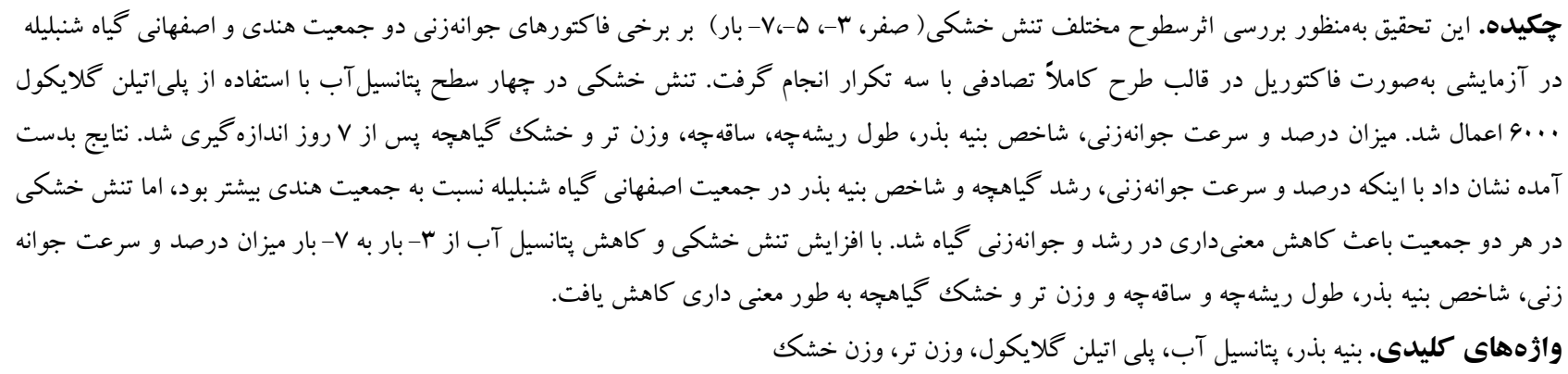

\title{
Effect of drought stress on germination characteristics of two populations of Fenugreek (Trigonella foenum subsp. graceum L.)
}

Zohre Zamani ${ }^{1}$, Hamzeh Amiri ${ }^{* *}$ \& Ahmad Ismaili ${ }^{2}$

Received 11/12/2016/ Revised 28.04.2018/ Accepted 01.05.2018/ Published 20.09.2018

${ }^{1}$ Department of Biology, Faculty of Sciences, Lorestan University, Khorramabad, Iran

${ }^{2}$ Department of Agronomy and Plant Breeding, Faculty of Agriculture, Lorestan University, Khorramabad, Iran

*Correspondent author: amiri.h@lu.ac.ir

\begin{abstract}
A laboratory research carried out to evaluate the effect of drought stress on germination characteristics in two 'Indian' and 'Isfahanian' populations of Fenugreek. This experiment performed in a factorial experiment based on a completely randomized design with three replicates. Four levels of drought stress applied by using polyethylene glycol 6000. Percentage of germination, germination rate, vigor index, root and shoot length as well as fresh and dry weight were measured after 7 days. The results showed that drought stress caused a significant reduction in both population growth and germination, although the percentage of germination, seedling growth and vigor index in the Isfahanian population was higher than the Indian. With the increase of water stress and the reduction of water potential from $-3 \mathrm{Bar}$ to $-7 \mathrm{Bar}$, the percentage of germination, vigor index, root and shoot length as well as fresh and dry weight significantly decreased.
\end{abstract}

Keyword. dry weight, fresh weight, polyethylene glycol, vigor index, water potential 
فاست كه در نتيجه آن جنين از حالت سكون بهحالت متابوليسمى

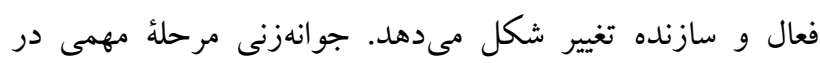

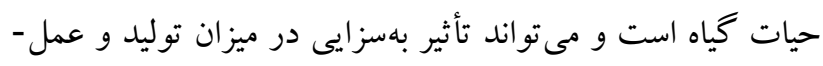

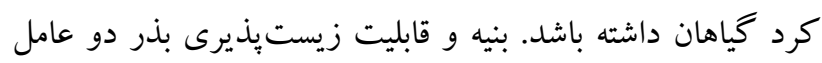

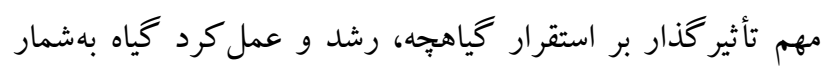

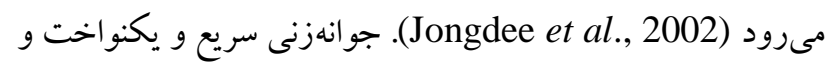
كامل بذرها باعث سطح سبز مطلوب و رشد اوليه و سريع گياهان

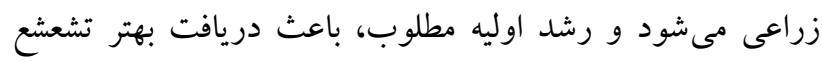

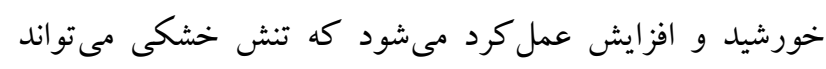
باعث كاهش سرعت و درصد جوانهزنى شود ( Parmer \& .(More, 2008 آب يكى از عوامل اصلى فعال كنندء جوانهزنى است و قابليت

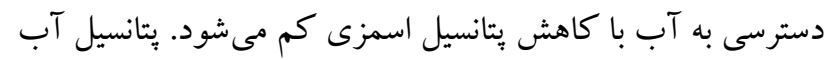

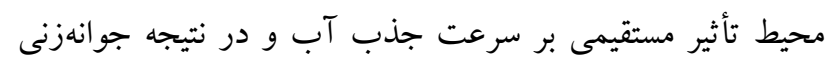

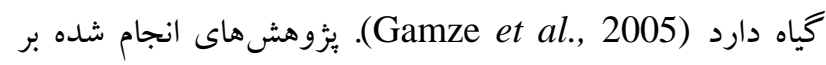
كياه شنبليله بيانكر اين واقعيت است كه با كاهش بِّانسيل آب،

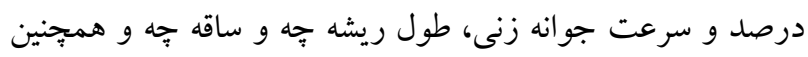

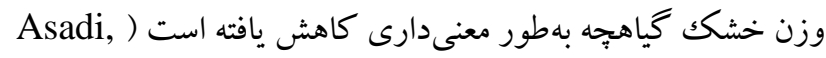
2009; Zaheer Ahmed \& Ajmal Khan, 2010 تحقيق با بررسى اثر سطوح مختلف تنش شورى بر جوانهزنى و

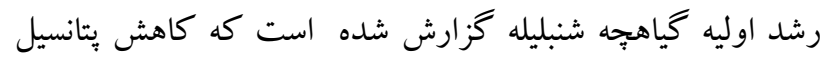

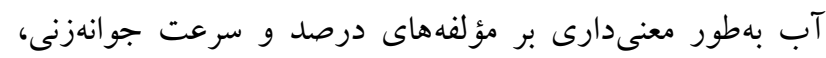

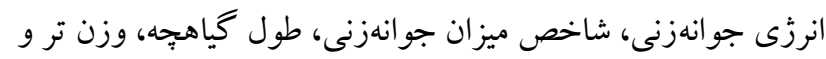
خشك گياهجه و شاخص بنيه بذر خياه شنبليله تأثير مى خذارد (Roumani \& Ehteshami, 2014) در شرايط تنش خشكى در بررسى بر روى نخود فرنكى( Pisum (Gativum L.

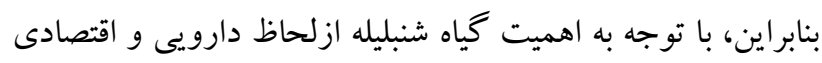

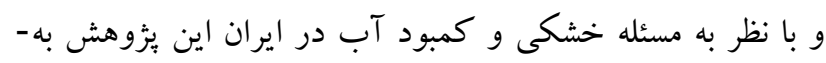

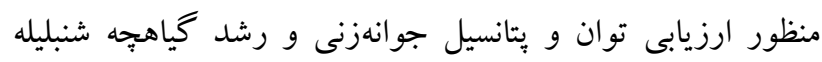
نسبت به سطوح مختلف خشكى و شناخت جمعيت مقاوم تر انجام

شلد.

\section{مواد و روشها}

بهمنظور بررسى اثر تنش خشكى بور جوان جوانه زنى دو جمعيت

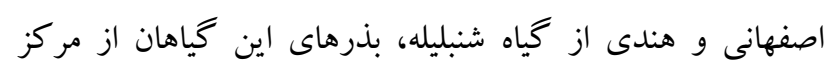

\section{مقلمه}

گرايش و تقاضاى بىسابقه و روزافزون به استفاده از خياهان دارويى در سيستم طب سنتى و صنعت داروسازى در سطح جهان،

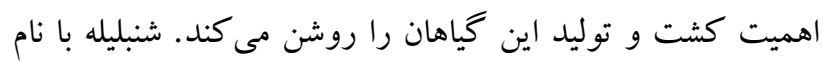
علمى Trigonella foenum subsp. graecum L. نهاندانه از دولِهاىهاى جداكلبر گك است كه جزء راسته كل

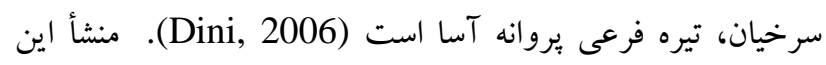
كياه نواحى آفريقاى شمالى و سو احل شرقى مديترانه است و بهوطور

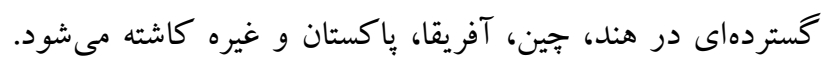

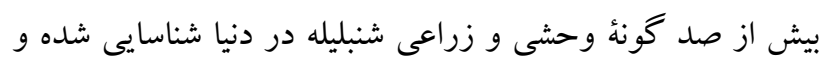

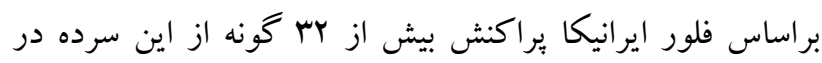

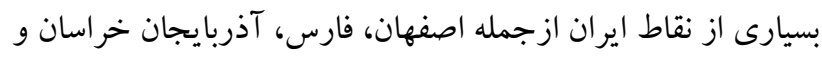

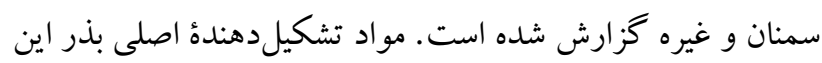

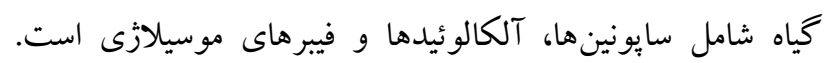

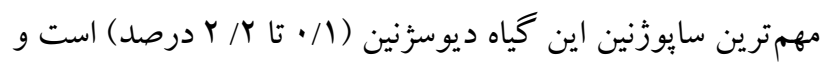

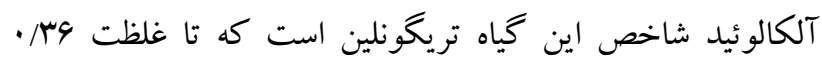
درصد استخراج شده است. در فارماكويههاى معتبر از دانههاى

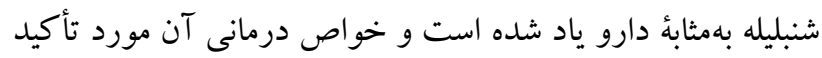

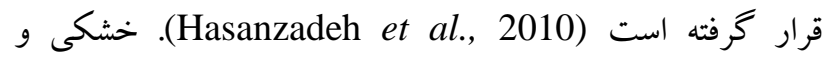
كمبود آب يكى از مهمترين عوامل محدود كنندة توليد محصول الدول در اكثر نقاط دنيا و ايران بهشمار مى آيد. در بسيارى از مناطق دنيا، تنشهاى زنده و غيرزنده محدودكنندة رشد و عمل كرد گياهان

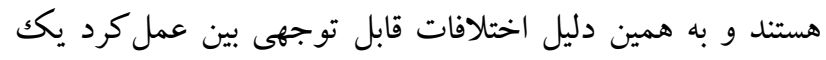

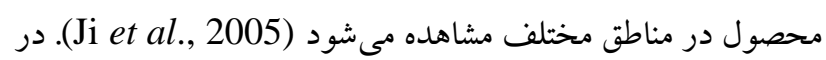

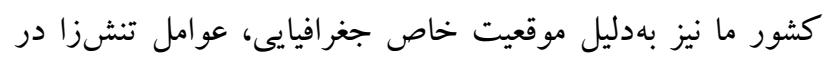

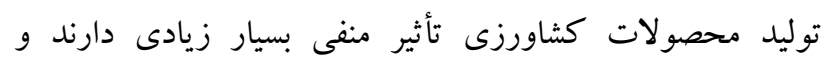
كثاورزى دراين مناطق با هزينههاى زياد و بازده كم همراه است.

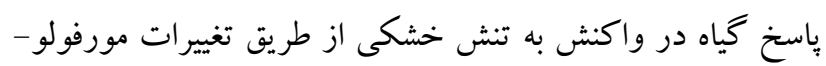

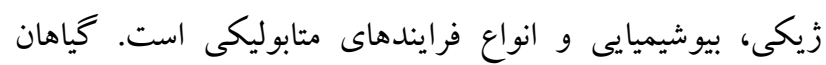

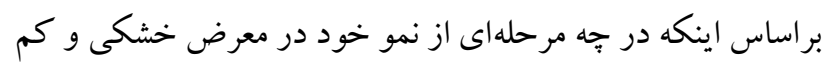

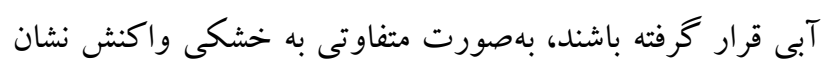

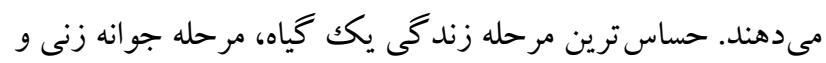

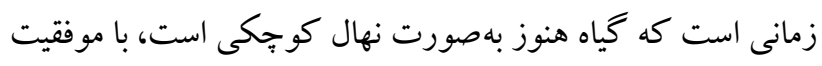
كذراندن اين دوره نقش بسيار مهمى در مراحل ديخر و استقرار

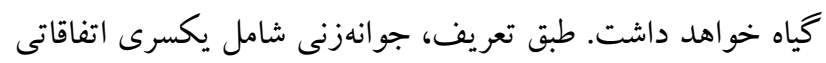


Ni

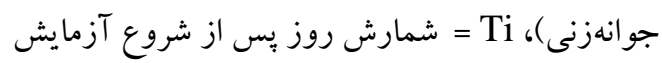

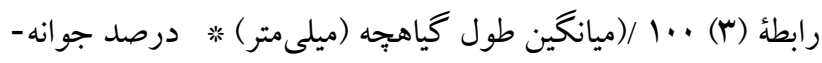
زنى نهايى) =شاخص بنيه بذر (مين

\section{نتايج}

\section{سرعت جوانهزنى بذر}

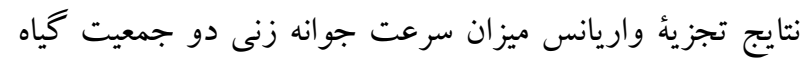

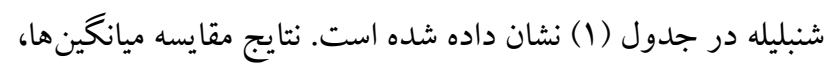
اختلاف معنىدار سرعت جوانهزنى در دو جمعيت اصفهانى و وتئل

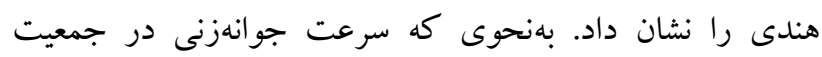

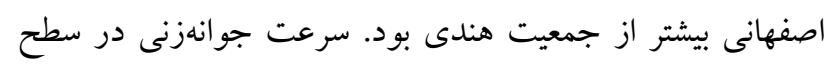

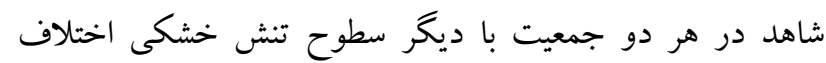

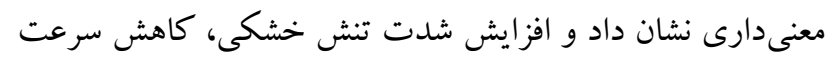
جوانه زنى را در بي داشت به نحوى كه در هر دو جمعيت، بيشترين

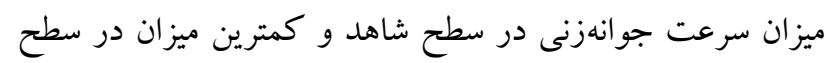
V- بار تنش خشكى مشاهده شد (شكل ()).

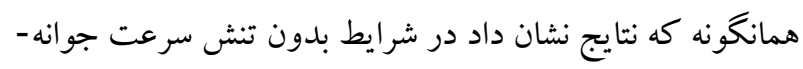

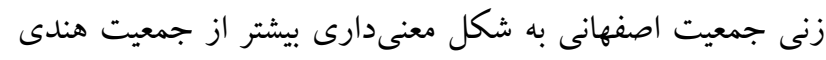
بود ولى در سطوح مختلف تنش خشكى اختلاف معنى دارى ميان سرعت جوانهزنى در دو جمعيت مشاهده نشد.

درصد جوانهزنى

نتايج تجزية واريانس درصد جوانهو دوانهزنى دو جمعيت گياه شنبليله

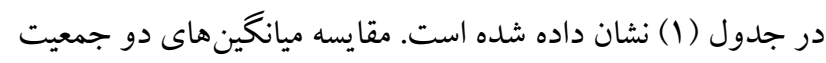
حاكى از اختلاف معنىدار درصد جوانهزنى در دو جمعيت

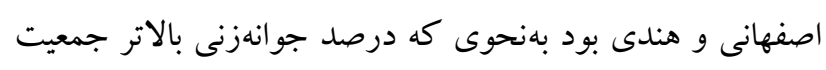

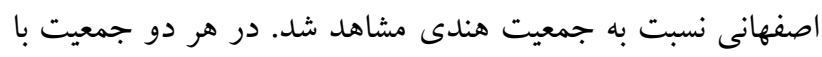
افزايش تنش خشكى درصد جوانهزنى كاهش يافت و بيشترين كاهش در سطح V- بار تنش خشكى مشاهده شد كه نسبت به ديخر

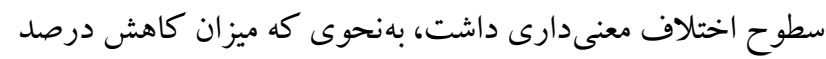
جوانهزنى در سطح V- بار تنش خشكى نسبت به سطح شاهد و و

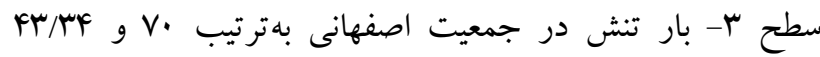

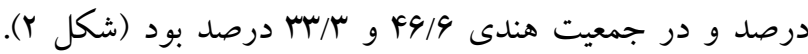
طول ساقه جه نتايج تجزيه واريانس مربوط به تغييرات طول ساقهجه دو جمعيت
تحقيقات كشاورزى استان اصفهان تهيه شدند. اين تحقيق در

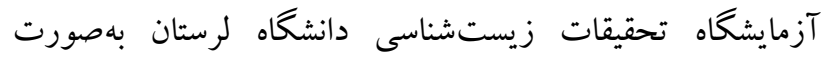
فاكتوريل در قالب طرح كاملاً تصادفى باسه تكرار تحت آزمايش

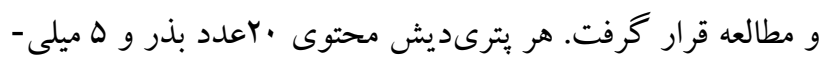

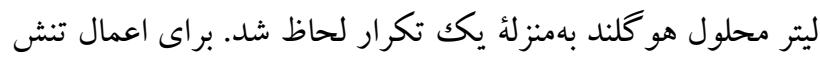

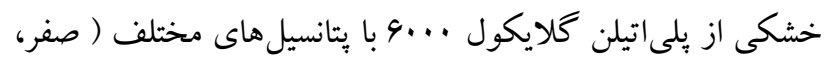

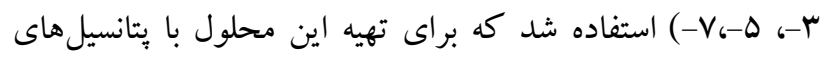

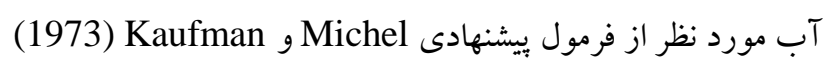
و براى گروه شاهد نيز از آب مقطر استفاده شد.

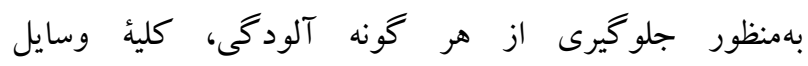
آزمايشكاهى، ظروف بترى، كاغذهاى صافى و... استريل شدند.

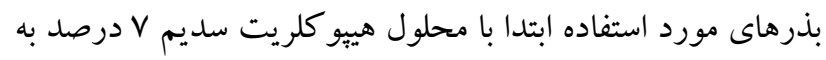

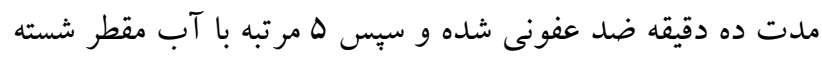

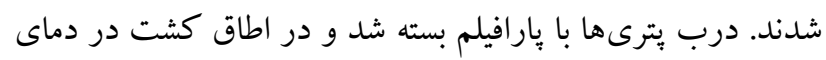

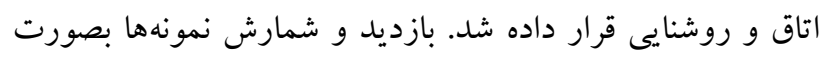

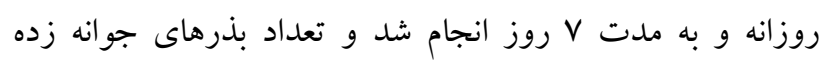

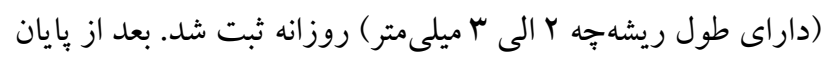

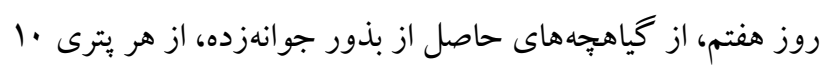

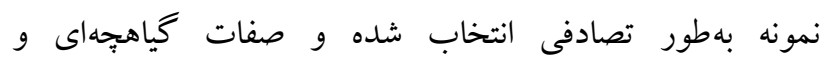
بارامترهاى جوانهزنى شامل درصد جوانه زنى، ميانگين سرعت

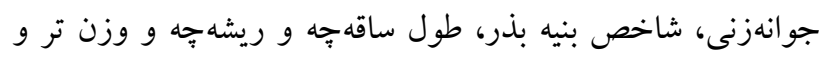

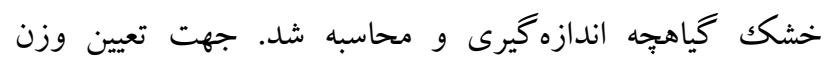

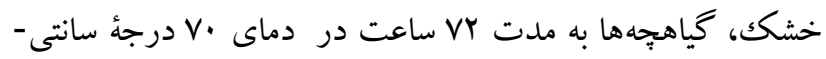

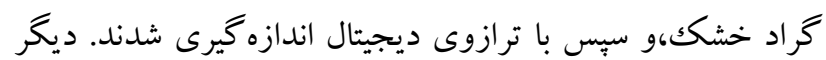

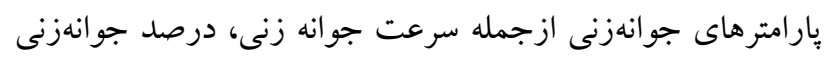

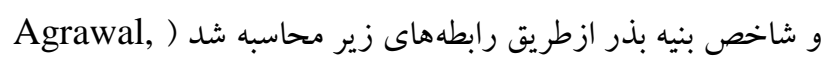

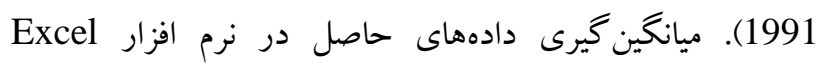

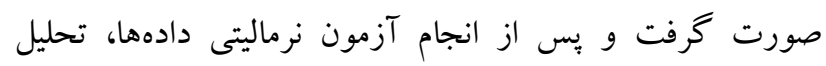

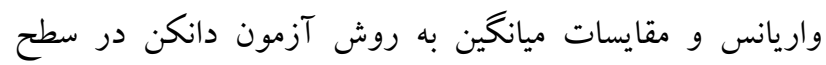

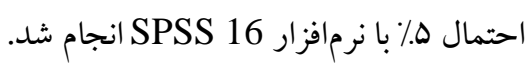

$\mathrm{PG}=\mathrm{Ni} / \mathrm{N} \times 10$

رابطة (1)

PG= درصد جوانهزنى، Ni= تعداد بذرهاى جوانهزده در روز أ ام

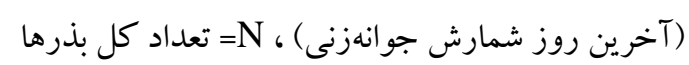
$\mathrm{GR}=\Sigma \mathrm{Ni}$

رابطة (r)

=/Ti GR 


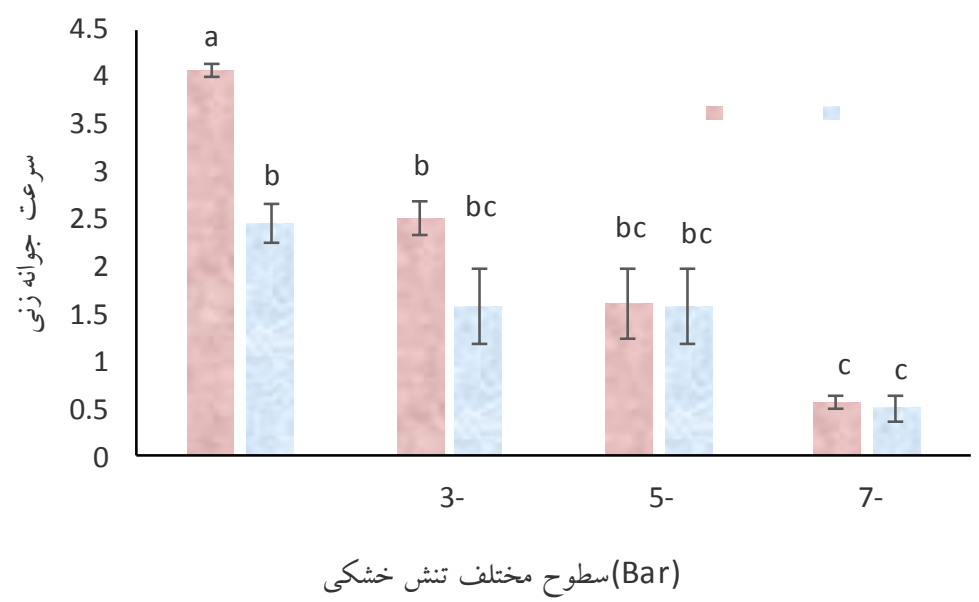

شكل ا- اثر سطوح مختلف تنش خشكى بر سرعت جوانهزنى دو جمعيت گياه شنبليله. خطوط روى ستونها نشاندهندة خطاى معيار است. (ستونهاى با حروف مشترك در سطح احتمال ه درصد به روش آزمون دانكن تفاوت معنى دارى با هم ندارند).

Fig. 1. Effect of drought stress on germiniation rate in Trigonella foenum subsp. graecum L. Bars on columns indicating standard error. (Columns having a common letter are not significantly different from each other according to Duncan 0.05).

$$
\text { جدول } 1 \text {-تجزيه واريانس بارامترهاى جوانهزنى. }
$$

Table 1. Analysis of variance of germination parameters.

\begin{tabular}{|c|c|c|c|c|c|c|c|c|}
\hline شاخص بنيه بذر & وزن خشك كياهجه & وزن تر گياهجه & طول ريشه & طول ساقه جه & جورانهزنى & درصد جوانه زنى & درجئ & منابع تغييرات \\
\hline $14439781^{* *}$ & $0.00002^{* *}$ & $0.0058^{* *}$ & $1224.16^{* *}$ & $197.504^{* * *}$ & $3515.1^{* *}$ & $7.68^{* *}$ & 3 & تنش خشكى \\
\hline $3627556^{*}$ & $0.000006^{* *}$ & $.0 .0002^{\mathrm{ns}}$ & $83.25^{\mathrm{ns}}$ & $6.827^{\mathrm{ns}}$ & $1204.2^{* *}$ & $2.62^{*}$ & 1 & جمعيت \\
\hline $325481^{\text {ns }}$ & $0.0000001^{\mathrm{ns}}$ & $0.00004^{\mathrm{ns}}$ & $68.66^{\mathrm{ns}}$ & $5.293^{\mathrm{ns}}$ & $215.3^{\text {ns }}$ & $0.88^{*}$ & 3 & تنش \\
\hline 593458 & 0.0000006 & 0.0003 & 65.52 & 2.150 & 125.0 & 0.20 & 16 & خطاى آزمايش \\
\hline
\end{tabular}

(1) نشان داده شده است. مقايسة ميانخين دادههاى مربوط به دو جمعيت نشان داد با كاهش يتانسيل آب از ب- بار به V- بار طول ريشهجه كاهش مىيابد. بيشترين طول ريشهجه در سطح ب- بار تنش خشكى در جمعيت اصفهانى مشاهده شد ولى تغييرات طول ريشهجه در اين سطح در جمعيت هندى نسبت به سطح شاهد معنى دار نبود و كمترين طول ريشهجه مربوط به جمعيت هندى در يتانسيل آب V- بار تنش خشكى بود كه نسبت به گروه شاهد و سطح ب- بار تنش خشكى اختلاف معنىدارى را نشان داد (شكل (f نتايج تجزية واريانس مربوط به تغييرات وزن تر گياهجه در دو جمعيت گياه شنبليله تحت سطوح مختلف تنش خشكى در جدول
كياه شنبليله تحت سطوح مختلف تنش خشكى در جدول (1) نشان داده شده است. نتايج مقايسه ميانگينها نشان داد كه با كاهش يتانسيل آب و افزايش تنش خشكى طول ساقهجه گياه در هر دو جمعيت كاهش يافت. در بين سطوح مختلف تنش خشكى سطح شاهد، بيشترين ميزان طول ساقهجه را در جمعيت اصفهانى داشت كه با ديكر سطوح تنش خشكى اختلاف معنىدارى نشان داد و كمترين ميزان طول ساقه جهه در سطح ه- تنش خشكى در جمعيت هندى مشاهده شد كه تنها با سطح شاهد و سطح ب- بار تنش خشكى اختلاف معنى دارى را نشان داد (شكل r). طول ريشه نتايج تجزيه واريانس مربوط به تغييرات طول ريشهجه در دو جمعيت گياه شنبليله تحت سطوح مختلف تنش خشكى در جدول 


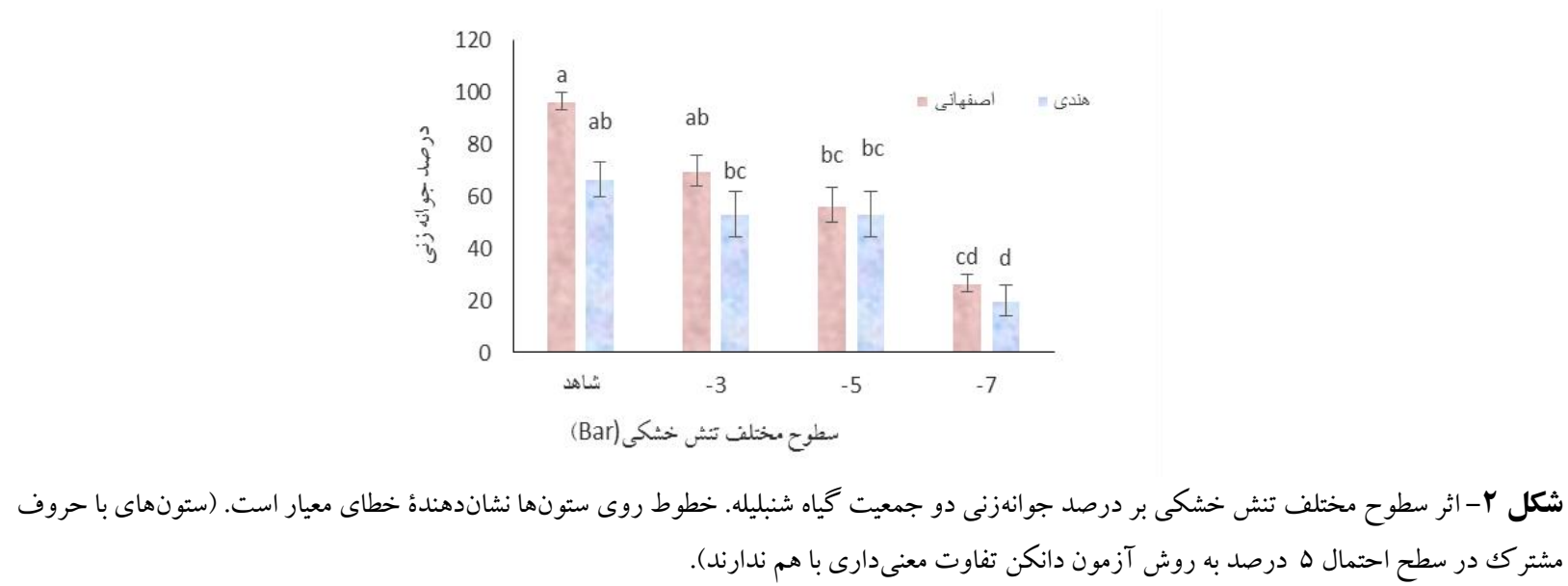

Fig. 2. Effect of drought stress on germination percentage in Trigonella foenum subsp. graecum L. Bars on columns indicating standard error. (Columns having a common letter are not significantly different from each other according to Duncan 0.05).

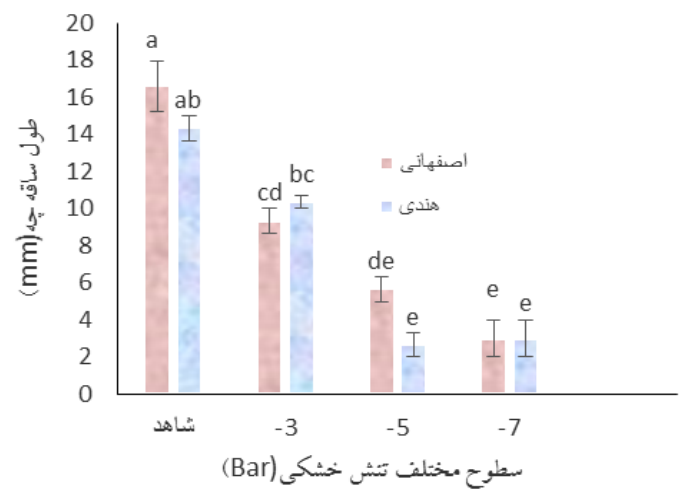

$$
\begin{aligned}
& \text { شكل r- اثر سطوح مختلف تنش خشكى بر طول ساقهجه دو جمعيت گياه شنبليله. خطوط روى ستونها نشاندهنده خطاى معيار است. (ستونهاى با حروف مشترك } \\
& \text { در سطح احتمال ه درصد به روش آزمون دانكن تفاوت معنىدارى با هم ندارند). }
\end{aligned}
$$

Fig. 3. Effect of drought stress on hypocotyl length in Trigonella foenum subsp. graecum L. Bars on columns indicating standard error. (Columns having a common letter are not significantly different from each other according to Duncan $0.05)$.

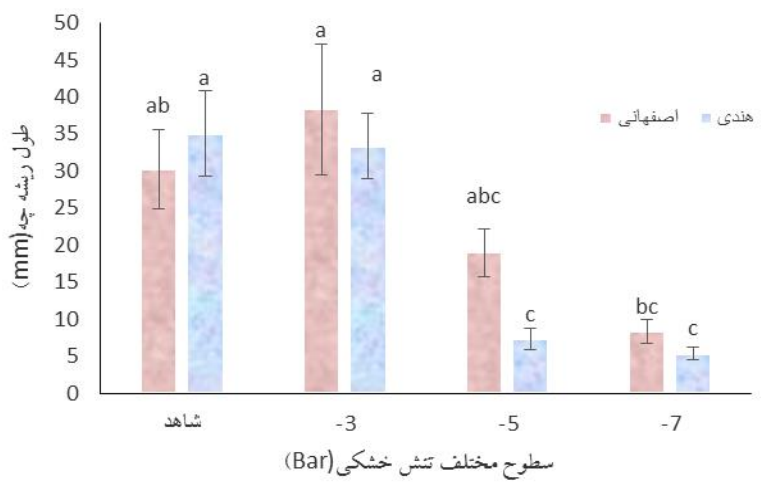

$$
\text { شكل ع- اثر سطوح مختلف تنش خشكى بر طول ريشه جه دو جمعيت گياه شنبليله. خطوط روى ستونها نشاندهنده خطاى معيار است. (ستونهاى با حروف مشتركى }
$$

Fig. 4. Effect of drought stress on radicle length in Trigonella foenum subsp. graecum L. Bars on columns indicating standard error. (Columns having a common letter are not significantly different from each other according to Duncan $0.05)$. 
Asadi, 2009; Zaheer- Ahmed \& Ajmal Khan, ) مى (2010; Armand et al., 2015

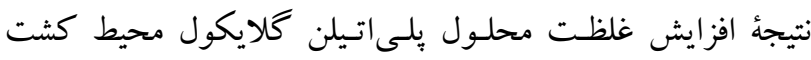
دانست كه به كاهش جذب آب توسط بذور منجر مىشود و و

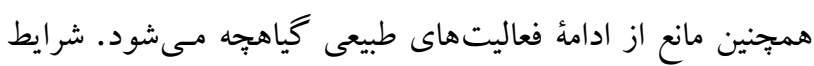

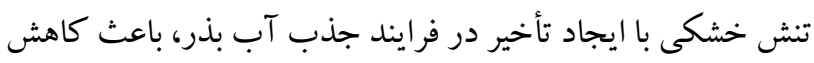

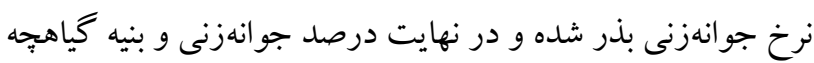

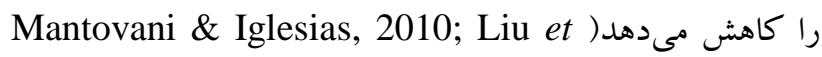

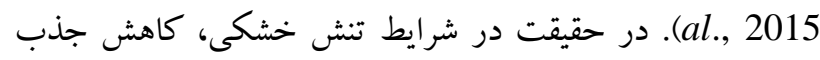

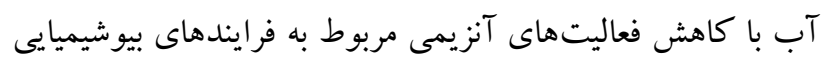
جوانهزنى همراه است كه علت اصلى كاهش سرعت جوانهزنى در شرايط تنش خشكى است. در سطوح بالاى تنش خشكى، آسيبهاى احتمالى ناشى از واسرشتشدن ساختمان سهبعدى آنزيمها دران

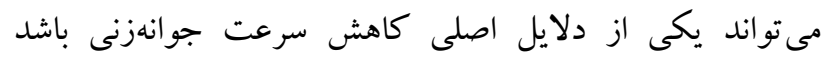

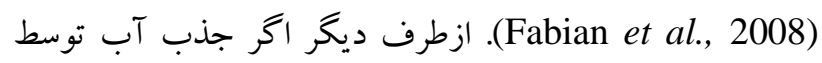

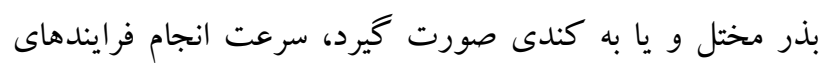
فيزيولوزيكى و متابوليكى در داخل بذر كاهش يأيل يافته و در نتيجه

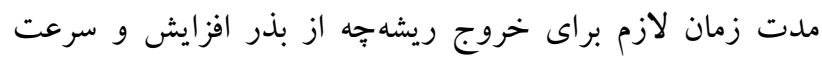

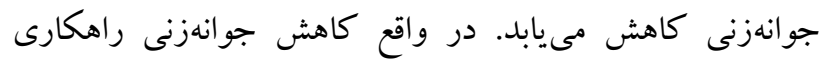
سازشى است تا زمانى كه شرايط مساعدى براى جوانهزنى ايجاد

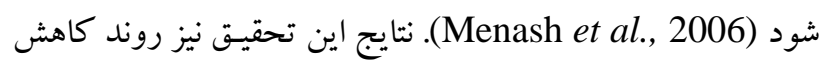

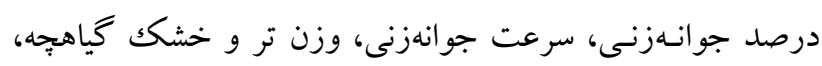

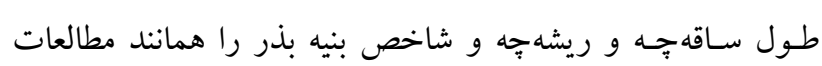

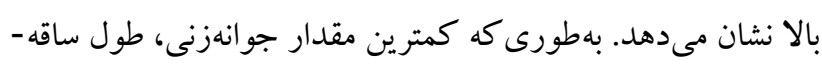

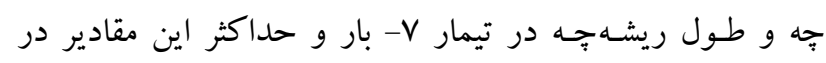

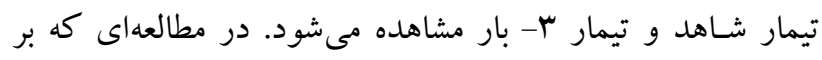

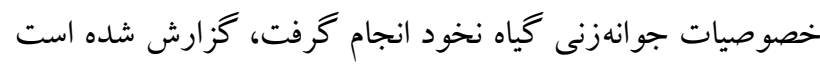

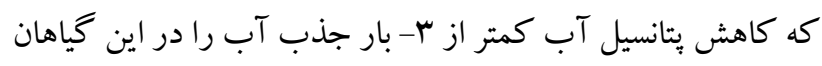

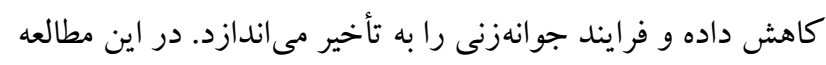

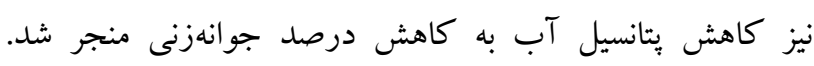

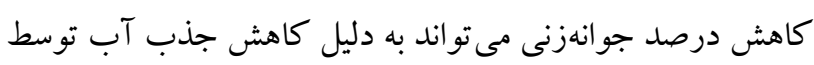

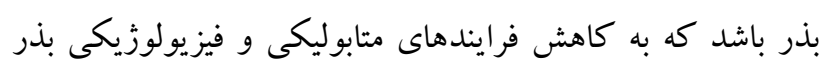

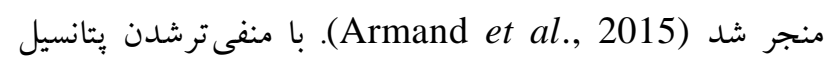
آب، فشار تورزسانس درون سلول كاهش يافته و مانع افزايش

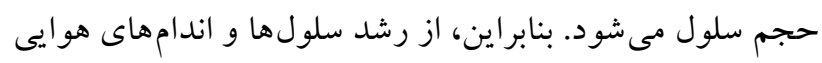

ا نشان داده شده است. كاربرد سطوح مختلف تنش خشكى اثر

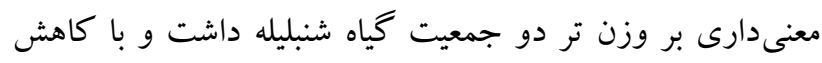

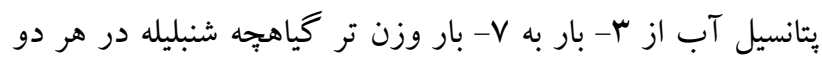

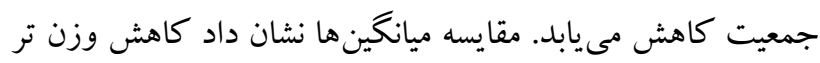

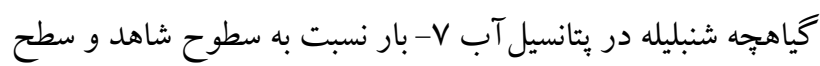
r-بار تنش خشكى معنىدار است. بيشترين مقدار وزن تر در هر دو

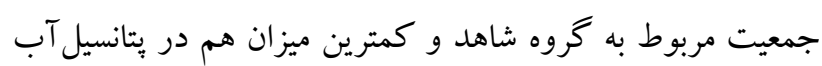
V- Vبار تنش خشكى مشاهده شد (شكل ه). وزن خشك نتايج تجزئ واريانس مربوط به تغييرات وزن خشك گياهجه در

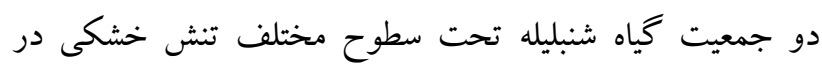
جدول (1) نشان داده شده است. مقايسٔ ميانخين دادهها حاكى از

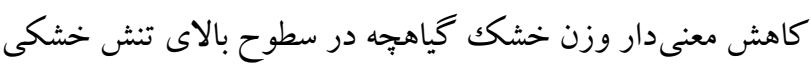

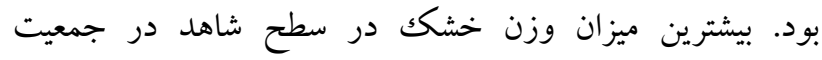

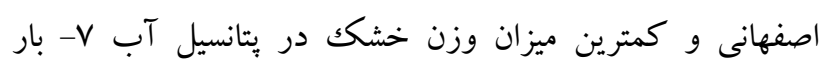
جمعيت هندى تنش خشكى اتفاق افتاد (شكل 9).

شاخص بنيه بذر نتايج تجزئ واريانس مربوط به شاخص بنيه بذر بذر دو جمعيت گياه شنبليل تحت سطوح مختلف تنش خشكى در جدول (1) نشان داده

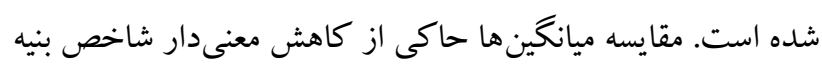
بذر دو جمعيت شنبليله تحت تأثير كاهش يتانسيل آب و اعمال تنش

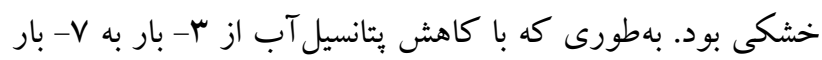

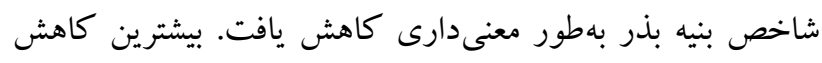

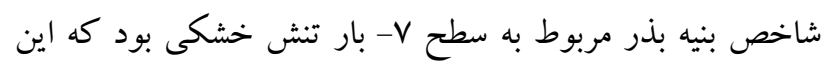

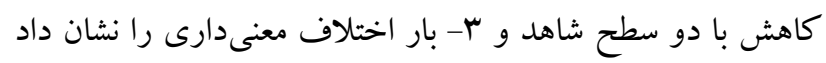

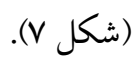

\section{بحث و نتيجه كيرى}

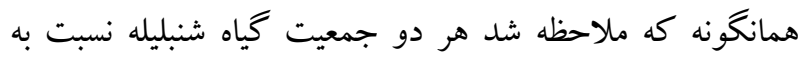

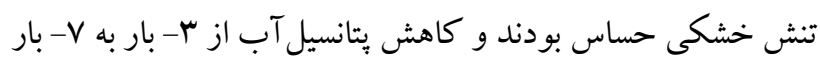

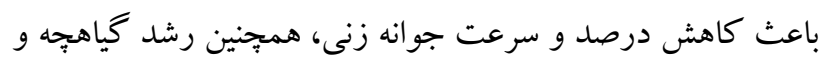

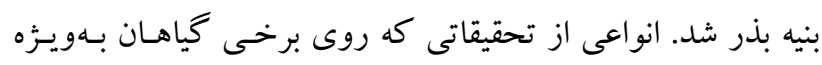
كياهان زراعى و كياهان دارويى مختلف انجام شده است، نشئ نشان

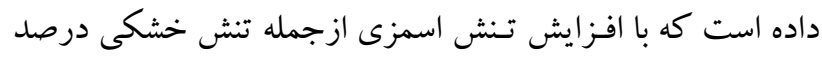

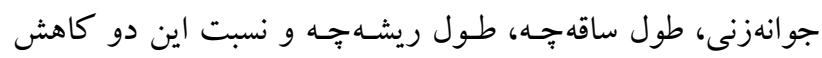




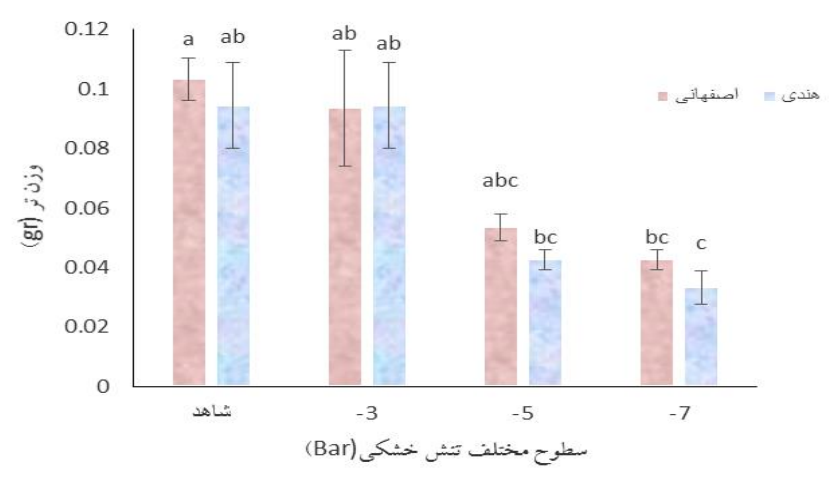

شكل 0- اثر سطوح مختلف تنش خشكى بر وزن تر دو جمعيت گياه شنبليل. خطوط روى ستونها نشاندهندة خطاى معيار است. (ستونهاى با حروف مشترك در

$$
\text { سطح احتمال هـ درصد به روش آزمون دانكن تفاوت معنى دارى با هم ندارند). }
$$

Fig. 5. Effect of drought stress on fresh weight in Trigonella foenum subsp. graecum L. Bars on columns indicating standard error. (Columns having a common letter are not significantly different from each other according to Duncan 0.05 ).

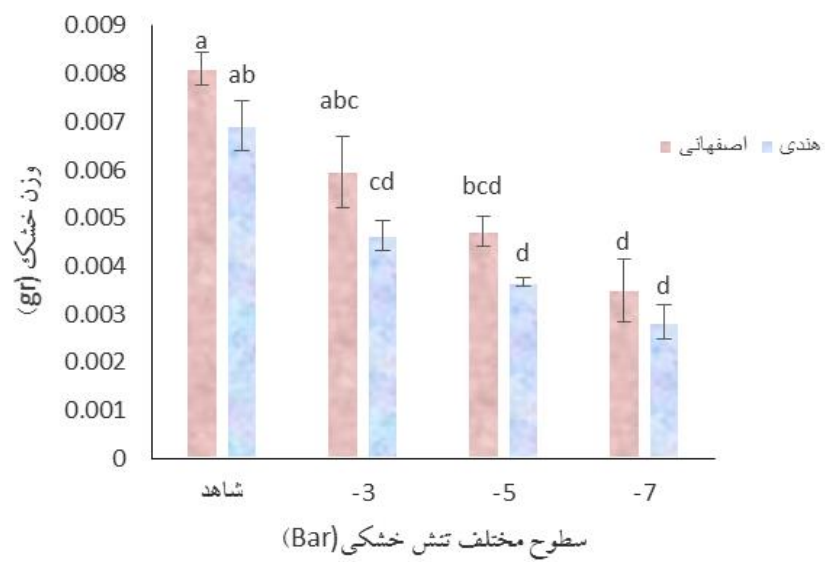

شكل ح- اثر سطوح مختلف تنش خشكى بر وزن خشك دو جمعيت گياه شنبليه. خطوط روى ستونها نشاندهنده خطاى معيار است. (ستونهاى با حروف مشترك در سطح احتمال هـ درصد به روش آزمون دانكن تفاوت معنى دارى با هم ندارند).

Fig. 6. Effect of Drought stress on dry weight in Trigonella foenum subsp. graecum L. Bars on columns indicating standard error. (Columns having a common letter are not significantly different from each other according to Duncan 0.05).

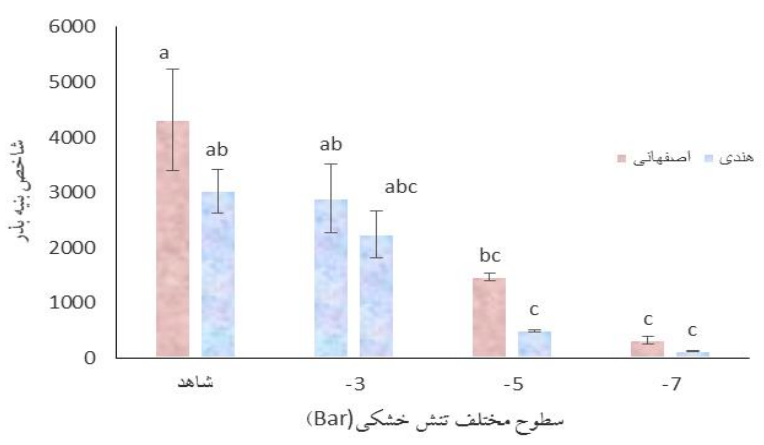

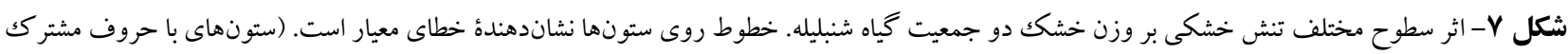

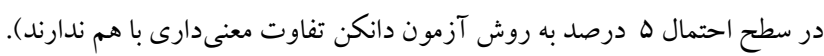

Fig. 7. Effect of drought stress on viability index in Trigonella foenum subsp. graecum L. Bars on columns indicating standard error. (Columns having a common letter are not significantly different from each other according to Duncan $0.05)$. 
ذكر شـده از خود مىدهند. لذا صرف مقاومت و يا حساسيت به

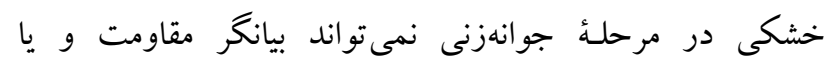
حساسيت گياه در مراحل ديخر رشـد باشد، ولى بهطور كلى، در كياهانى كه داراى مقاومت و رشـد بيشتر ريشهجه و ساقهجهـ در ايـن مرحلـه باشـند، در مرحلـه كياهجه و مراحل ديخر نيـز مقاومست بيشـترى بـه خشـكى از خود نشان خواهند داد. در خايان

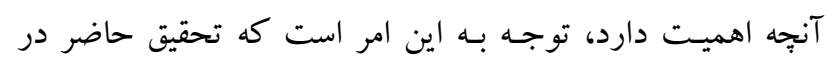

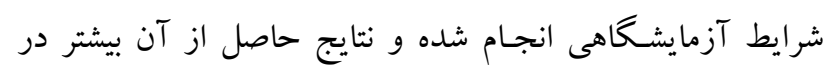

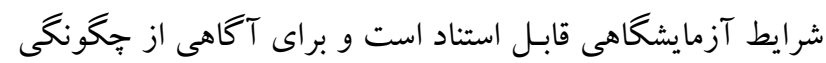
عكس العمل آنها بـه تنش خشكى در مرحله جوانهزنى در شرايط طبيعى لازم است كه همانند آزمايش فوق در شـرايط طبيعى و در منـاطق مختلف انجام شود تا با نتايج بهدست آمده بتوان مقـاوم تـرين جمعيت را در اين مرحله معرفى كرد.

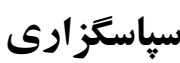

بدينوسيله از حمايت هاى مالى دانشگاه لرستان جهت انجام اين

$$
\text { يزؤش قدردانى مىنمايم. }
$$

\section{REFRENCES}

Agrawal, R.L. 1991. Seed technology. Second edition. Oxford and IBH press. New York and London. pp: 445.

Akhavan-armaki, M., Hashemi, M., Azarnivand, H., Osare, M. H., Jafari, A.A. and Tavili A. 2013. Effect of drought stress on growth and germination characteristics of three genotype of Agropyron trichophorum. - Desert Eco. Eng. J. 2: 9-14.

Armand, N., Amiri, H. and Ismaeili, A. 2015. Effect of methanol on germination characteristics of bean (Phaseolus vulgaris L. cv. Sadry) under drought stress condition. - Iran. J. Pulses Res. 6: 42-53.

Asadi, A. 2009. Investigation of salinity stress on seed germination of Trigonella foenum subsp. graecum - J. Biochem. Sci. 4: 1152-1155.

Dini, M. 2006. Scientific name of medicinal plants used in traditional medicine. - Forest and Rangeland Res. Inst. Pub. Iran. 299-300.

Fabian, A., Jager, K. and Barnabas, B. 2008. Effects of drought and combined drought and heat stress on germination ability and seminal root growth of wheat (Triticum aestivum L.) seedlings. - J. Acta Biologica 52: 157-159.

Farhadi, H., Azizi, M. and Nemati, S.H. 2015. Effect of salinity on traits related with performance in eight native population of fenugreek (Trigonella foenum subsp. graecum). - Iran. J. Field Crops Res. 12: 862870 .
جلو گيرى مىشود (Akhavan-armaki, 2013) و همانند نتايج اين تحقيق كاهش وزن تر و خشك و كاهش طول ساقهجه و

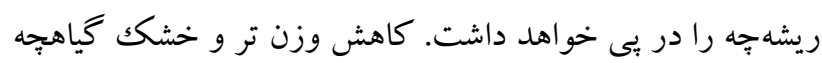
از رخدادهاى رايجى است كه در اكثر گياهان در شرايط تنش خشكى اتفاق مى افتد. يكى از دلايل كاهش وزن در يتانسيل هاى آب پايين، تحركك كم مواد غذايى و انتقال كمتر آنها از لِه به

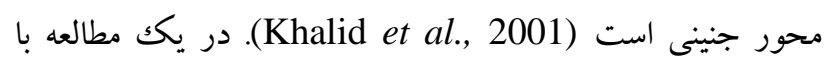
بررسى تأثير تنش خشكى اعمالشده توسط 6000 PEG بر

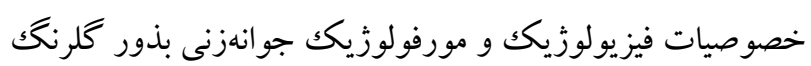
Carthamus tinctorius خشكى، كاهش ميزان سرعت جوانهزنى و درصد جوانهزنى با كاهش يتانسيل آب در زنوتيبٍ هاى حساس به خشكى گز ارش شد (Zabarjadi et al., 2012) در اين تحقيق نيز با اينكه هر دو جمعيت، مقاومت كمى نسبت به شرايط تنش اعمالشده نشان دادند و تمام پارامترهاى مربوط به جوانهزنى با افزايش تنش، روند كاهشى داشتند اما جمعيت اصفهانى نسبت به جمعيت هندى مقادير بالاترى از رشد و جوانهزنى را هم در شرايط تنش و هم شرايط بدون تنش نشان دادند. براساس نتايج يكك تحقيق با بررسى اثر تنش شورى بر جمعيتهاى مختلف كياه شنبليله، مقاومت بيشتر جمعيت اصفهانى نسبت به ديخر جمعيت ها در مقابل به تنش شورى گزارش شد و جمعيت اصفهانى تحت نام جمعيت حاوى زنهاى متحمل به شورى معرفى شد. (Farhadi et al., 2015). همانكونه كه نتايج اين تحقيق نشان داد جمعيت اصفهانى در مرحله جوانهزنى نيز تحت شرايط تنش خشكى كه هماند تنش شورى نوعى تنش اسمزى محسوب مىشود، عمل كرد قوىترى نسبت به جمعيت هندى داشت. درحقيقت تفاوت در شرايط اكولوزيكى كه دو جمعيت مذكور در آن رشد يافتهاند باعث اعطاى ويز گیى هاى فيزيولوزيكى متفاوت در آنها شده است. در طى تحقيقات مختلفى كه در زمينه مقاومت كياهـان زراعى و دارويى در برابـر تـنش خشكى انجام شده است، نتايج متفاوتى بـهدست آمـده اسـت. بـهوروى كه برخى از خياهان در مرحله جوانه زنى در برابر تـنش خشكى، مقاومست كمسى از خـود نشـان داده و نسـبت بـه آن حساس بوده اند، اما در مراحل

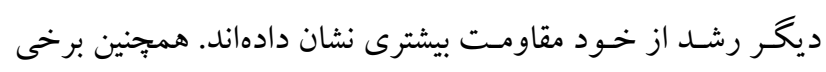
ديخـر از كياهـان وجـود داشتهاند كه نتيجهُ معكوسى نسبت به نتيجه 
Gamze, O., Mehmet Demir, K.A.Y. and Mehmet, A.T.A. 2005. Effects of salt and drought stresses on germination and seedling growth of pea (Pisum sativum L.). - Turk. J. Agri. 29: 237- 242.

Hasanzadeh, A., Rezazade, S.H., Shamsa, S. F., Dolat Abadi, R. and Zaringhalam, J. 2010. A review on the medical and phytochemical properties of fenugreek. J. Medicin. Plant. 2: 1-18.

Ji, X.M., Raveendran, M., Oane, R., Ismail, A. Lafitte1, R., Bruskiewich, R., Cheng, S.H. and Bennett, J. 2005. Tissue-specific expression and drought responsiveness of cell-wall invertase genes of rice at flowering. - Plant Mol. Biol. 59: 945-964.

Jongdee, B., Fukai, S. and Cooper, M. 2002. Leaf water potential and osmotic adjustment as physiological traits to improve drought tolerance in rice. - Field Crops Res. 79: 153-163.

Liu, M., Li, M., Liu, K. and Sui, N. 2015. Effects of drought stress on seed germination and seedling growth of different maize varieties. - J. Agri. Sci. 7: 231-240.

Michel, B.E. and Kaufman, M.R. 1973. The osmotic potential of polyethylene glycol 6000. - Physiol. 51: 914-916.

Khalid, M. N., Iqbal, H.F., Tahir, A. and Ahmad, A.N. 2001. Germination potential of chickpeas (Cicer arietinum L.) under saline condition. - J. Biol. Sci. 4: 395-396.

Mantovani, A and Iglesias, R.R. 2010. The effect of water stress on seed germination of three terrestrial bromeliads from restinga. - Braz. J. Bot. 33: 201-205.

Mensah, J. K., Obadoni, B.O., Eruotor, P.G. and Onome, F. 2006. Simulated flooding and drought effects on germination, growth and yield parameters of sesame (Sesamum indicum L.). - Afric. J. Biol. 5: 1249-1253.

Roumani, A. and Ehteshami, M. 2014. Effect of different levels of salinity stress on seed germination and early growth of fenugreek (Trigonella foenum L.) seedling. - Iran. J. Seed Res. 1: 33-45.

Parmer, M.T. and More, R.P. 2008. Carbowax 6000, Maintol, Sodiumchloride for simulating drought condition in germination studies of corn (Zea mays) of strong and weak vigor. - Agro. J. 60: 192-195.

Zaheer Ahmed, M. and Ajmal Khan, M. 2010. Tolerance and recovery responses of playa halophytes to light, salinity and temperature stresses during seed germination. - Flora Morph. Distribut. Func. Eco. Plants. 205: 764-771.

Zebarjadi, A.R., Soheilikhah, Z.H., Ghasempour H.R. and Vaisipour, A. 2012. Effect of drought-induced stress by PEG6000 on physiological and morphological traits of Safflower (Carthamus tinctorius) seed germination in order to selection of drought tolerant genotypes. - Iran. J. Boil. 25: 252263.
How to cite this article:

Zamani, Z., Amiri, H. and Ismaili, A. 2018. Effect of drought stress on germination characteristics of two populations of Fenugreek (Trigonella foenum subsp. graceum L.). - Nova Biologica Rep. 2018: 183-191.

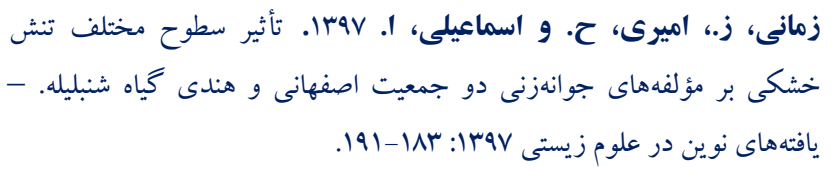


